\title{
Synthesis, Characterization and Biological Evaluations of Ciprofloxacin Carboxamide Analogues
}

\author{
Najma Sultana, ${ }^{\dagger}$ Muhammad Saeed Arayne, Syeda Bushra Shakeb Rizvi, ${ }^{\ddagger}, *$ and Urooj Haroon ${ }^{\S}$ \\ Department of Chemistry, University of Karachi, Karachi-75270, Pakistan \\ 'Department of Pharmaceutical Chemistry, Research Institute of Pharmaceutical Sciences, Faculty of Pharmacy, \\ University of Karachi, Karachi-75270, Pakistan \\ "Department of Pharmaceutical Chemistry, Faculty of Pharmacy Federal Urdu University of Arts, \\ Science and Technology, Karachi, Pakistan. ${ }^{*}$ E-mail: sbushrarizvi@gmail.com \\ ${ }^{\S}$ Department of Chemistry, Federal Urdu University of Arts, Science and Technology, Karachi, Pakistan \\ Received June 23, 2010, Accepted November 30, 2010
}

\begin{abstract}
Present work comprises of synthesis various analogues of ciprofloxacin by introducing new functionality at carboxylic group position via ester aminolysis reaction. For this purpose the carboxylic group at C-3 was esterified and later subjected to nucleophilic attack at the carbonyl carbon by various aromatic amines. Structure of the analogues was confirmed by different techniques i.e. IR, ${ }^{1} \mathrm{H}$ NMR and mass spectrometry. The antibacterial activity of the derivatives was also assessed with the parent against a series of Gram-positive and Gram-negative bacteria. The synthesized compounds showed diverse antimicrobial profile among which most compounds possessed a comparable or better activity in comparison to the ciprofloxacin. Additionally unlike ciprofloxacin, some of the derivatives were also found to show antifungal activity.
\end{abstract}

Key Words: Ciprofloxacin, Ester aminolysis reaction, Antibacterial activity, Antifungal activity

\section{Introduction}

Fluoroquinolones have a very useful role in the treatment of many bacterial infections ${ }^{1,2}$ Ciprofloxacin (Figure 1), 1-cyclopropyl-6-fluoro-1,4-dihydro-4-oxo-7-(1-piperazinyl)-3-quinolinecarboxylic acid $\left(\mathrm{C}_{17} \mathrm{H}_{18} \mathrm{FN}_{3} \mathrm{O}_{3}\right)$ is a broad spectrum antibiotic belongs to second generation of flouroquinolone. It inhibits DNA relplication, repair of bacterial DNA and RNA transcription of Gram negative and Gram positive cocci acting upon DNA topoisomerase enzyme ${ }^{3}$ which eventually leads to blockage of bacterial cell growth.,

Advances in quinolone field are likely to provide better compounds capable of dealing with the resistant strains. These research efforts have been rewarded by very significant improvements in antibacterial potency as well as in vivo efficacy. Most of the quinolone antibacterial research has been focused on the functionality at $\mathrm{C}-7$ position. ${ }^{6}$ The structure activity relationship (SAR) reveals that the $\mathrm{C}-7$ substituent is the most adaptable site for chemical change and is an area that determines potency
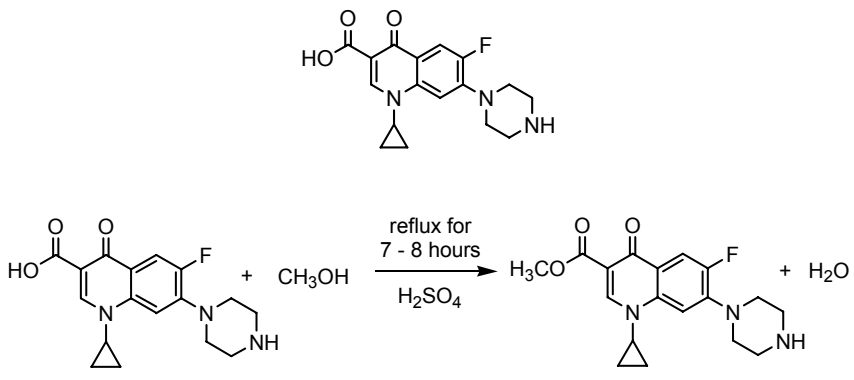

Ciprofloxacin

Ester Intermediate of Ciprofloxacin

Figure 1. Ciprofloxacin. and target preference. ${ }^{7}$ During recent years a number of quinolones with substitution on piperazine ring at C-7 position of the basic structure of quinolones were synthesized. ${ }^{8,9}$ The hypothesis of this study was that new fluoroquinolone agents with a carbon-linked nitrogen-containing side chain at the C-7 of the quinolone-carboxylic acid nucleus may offer new insight into the structural-activity relation of the quinolone antibacterials. ${ }^{10,11}$

Because of the lack of data in the literature concerning analogues of quinolones at carboxylic position, to investigate the potential of 3-carboxylic quinolone derivatives as anti Gram positive and Gram negative agents, we have recently reported some novel levofloxacin, ${ }^{12}$ enoxacin ${ }^{13}$ carboxamide analogues. In extension of our previous work we are reporting here second generation broad spectrum azafluoroquinolone antibacterial agents, by introducing new functionality at carboxylic group position. These efforts on fluoroquinolone research have intensified their activity against Gram-positive organisms as well as on Gram-negative organisms.

The present study enlightens the synthesis, spectroscopic analysis (including IR and ${ }^{1} \mathrm{HNMR}$ ), mass spectrometry and evaluation of biological activities of ciprofloxacin carboxylic derivatives carrying amino-containing aromatic ring.

\section{Experimental}

Material and Equipments. Ciprofloxacin was gift from Ali Gohar Pharmaceutical Ltd., Karachi, Pakistan. All the reagents used were of analytical grade. All the glassware was washed with chromic acid followed by a thorough washing with freshly prepared de-ionized water.

Melting points were obtained manually by capillary method. The IR spectra were obtained on shimadzu prestige-21 $200 \mathrm{VCE}$ 


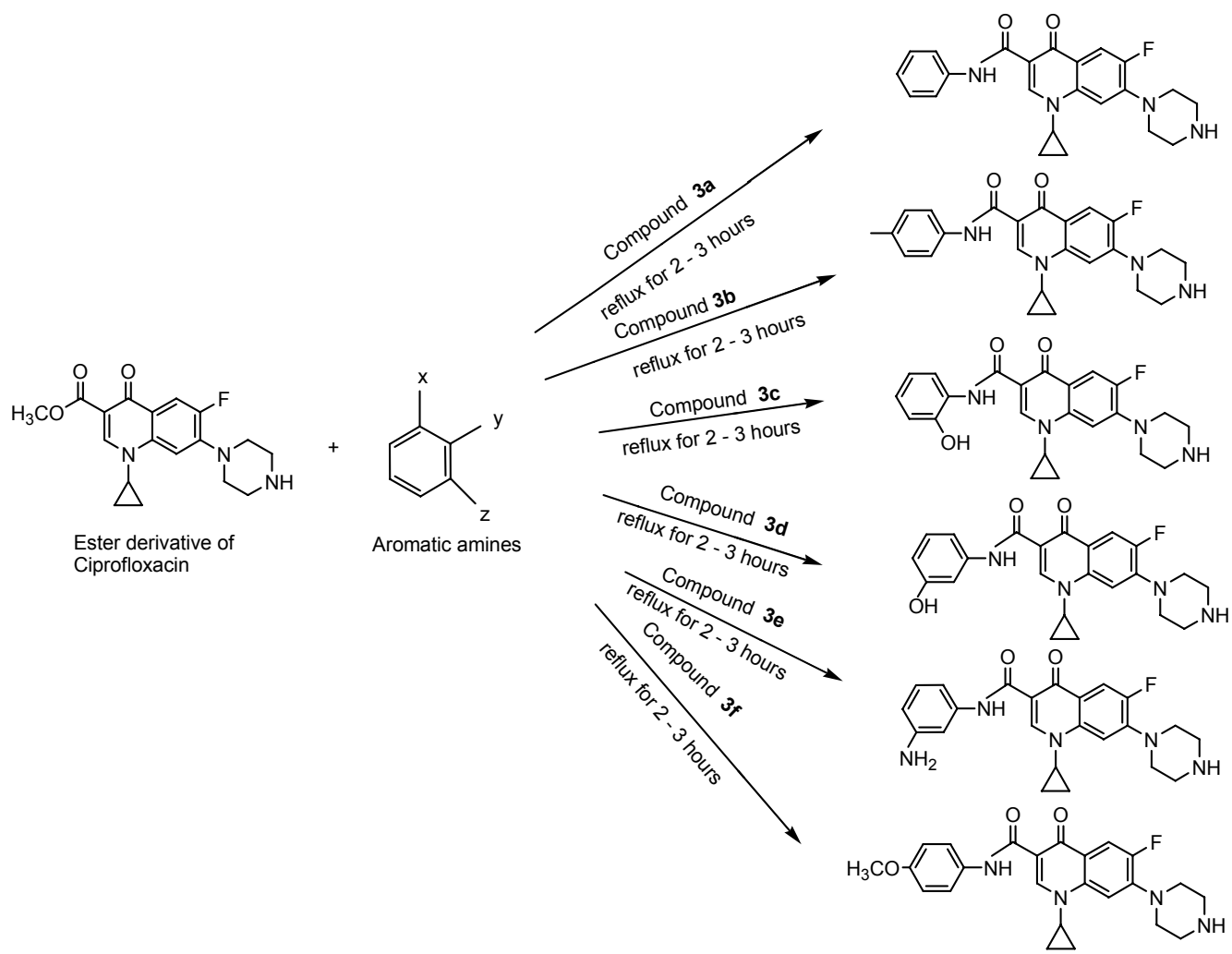

3a; $x=\mathrm{NH}_{2}, y=\mathrm{H}, \mathrm{z}=\mathrm{H}$ (Aniline)

3c; $\mathrm{x}=\mathrm{NH}_{2}, y=\mathrm{OH}, \mathrm{z}=\mathrm{H}$ (o'amino phenol)

3e; $x=\mathrm{NH}_{2}, y=\mathrm{H}, \mathrm{z}=\mathrm{NH}_{2}$ (Phenylenediamine) 3b; $\mathbf{x}=\mathrm{NH}_{2}, \mathrm{y}=\mathrm{H}, \quad \mathrm{z}=\mathrm{CH}_{3}$ (Toluidine)

3d; $\mathrm{x}=\mathrm{NH}_{2}, y=\mathrm{H}, \mathrm{z}=\mathrm{OH}$ (3' aminophenol)

3f; $\mathrm{x}=\mathrm{NH}_{2}, \mathrm{y}=\mathrm{H}, \mathrm{z}=\mathrm{OCH}_{3}$ (Anisidine)

Figure 2. Synthetic pathway of series 3a-3f analogues.

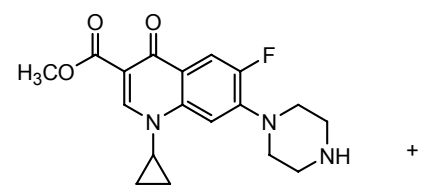

Ester derivative of Ciprofloxacin

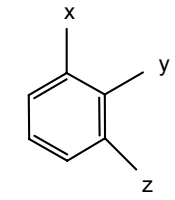

Aromatic amines
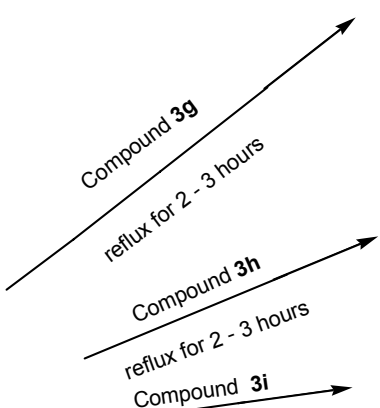

Compound $3 i$

reflux for $2-3$ hours

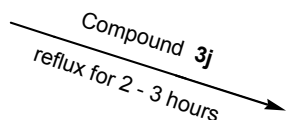<smiles>NC(=O)c1cn(C2CC2)c2cc(N3CCNCC3)c(F)cc2c1=O</smiles><smiles>O=C(NNc1ccccc1)c1cn(C2CC2)c2cc(N3CCNCC3)c(F)cc2c1=O</smiles><smiles>O=C(NC(=O)c1cn(C2CC2)c2cc(N3CCNCC3)c(F)cc2c1=O)c1ccccc1</smiles><smiles>O=C1c2ccccc2C(=O)N1C(=O)c1cn(C2CC2)c2cc(N3CCNCC3)c(F)cc2c1=O</smiles>

3g; $\mathrm{x}=\mathrm{H}, \mathrm{y}$ and $\mathrm{z}=$ (phy) $\mathrm{NH}_{2}$ (Alpha naphthylamine) 3i; $x=H, y=H, z=\mathrm{CONH}_{2}$ (Benzamide) 3h; $\mathrm{x}=\mathrm{NH}-\mathrm{NH}_{2}, \mathrm{y}=\mathrm{H}, \mathrm{z}=\mathrm{H}$ (Phenylhydazine)

3j; $\mathrm{x}=\mathrm{H}, \mathrm{y}$ and $\mathrm{z}=(\mathrm{CO})_{2} \mathrm{NH}$ (Phthalimide)

Figure 3. Synthetic pathway of series $\mathbf{3 g}-\mathbf{3 j}$ analogue. 
coupled to a P IV- PC and loaded with IR solution version 1.2 software (potassium bromide disks). The absorption peaks were recorded in frequency $\left(\mathrm{cm}^{-1}\right)$. NMR spectra were recorded on Bruker FT - NMR $500 \mathrm{MHz}$ with the compounds dissolved in deuterated methanol. Chemical shifts are reported in parts per million $(\delta)$ relative to tetra methyl silane as an internal standard. Significant ${ }^{1} \mathrm{H}$ NMR data are tabulated in the following order: multiplicity (s, singlet; d, doublet; $\mathrm{t}$, triplet; q, quartet; and $\mathrm{m}$, multiplet); and number of proton(s). The mass spectra were recorded on Finnign-MAT212 under electron impact (EI) ionization condition. Thin layer chromatography (TLC) was performed on HSF-254 TLC plate and compounds visualized under UV lamp.

General Procedure for Preparation of Derivatives (3a-3j). Synthesis of various derivatives of ciprofloxacin was attempted with various aromatic amines i.e., aniline, toludine, $o$-aminophenol, 3'aminophenol, phenylenediamine, anisidine, $\alpha$-naphthylamine, phenylhydraize, benzamide and phthalimide. Ciprofloxacin ( 0.01 moles) was added to the round bottomed flask containing $60 \mathrm{~mL}$ of methanol. $1 \mathrm{~mL}$ of sulphuric acid was added to the flask and the reaction was refluxed for about $7-8$ hours. After the consumption of ciprofloxacin (examined by TLC) 0.01 molar solutions of aromatic amines (prepared in methanol) were added individually with continuous stirring and the reaction was again refluxed for about 2 - 3 hours till completion, indicated by TLC. While for compound $\mathbf{3 i}$ and $\mathbf{3 j} \mathrm{jaOH}$ was added in the methanolic mixture of benzamide and phthalimide and heat it afterwards they were added in the reaction flask containing ciprofloxacin ester intermediate. Reaction was again refluxed for about 2 - 3 hours till completion. Thin layer chromatography was used to monitor reaction. The volume of the reaction mixture was then reduced by rotary-evaporation. The precipitates were filtrated off, washed with methanol-chloroform (2:8) to give compound.

\section{Spectral Data.}

1-Cyclopropyl- $\mathrm{N}$-phenyl-6-fluoro-4-oxo-7-(piperazinyl)1,4-dihydro-3-quinoline Carboxamide (3a): $\left(\mathrm{C}_{23} \mathrm{H}_{23} \mathrm{FN}_{4} \mathrm{O}_{2}\right)$ yield; $68 \%$, mp $271{ }^{\circ} \mathrm{C}$, IR $(\mathrm{KBr}) v_{\max } ; 1660,1622(\mathrm{C}=\mathrm{O})$ and $3167(\mathrm{~N}-\mathrm{H}) \mathrm{cm}^{-1},{ }^{1} \mathrm{H}-\mathrm{NMR}\left(300 \mathrm{MHz}-\mathrm{CDCl}_{3}\right) \delta 8.08(\mathrm{~s}, 1 \mathrm{H}$, 2' $\operatorname{aryl} \mathrm{H}), 7.19$ (d, 1H, 5' aryl H, $J=12.98), 3.47 ; 2.78$ (m, 8H, piperznyl H), 5.93 (s, 1H, 8'aryl H), 0.53;028 (m, 4H, cyclopropane), 1.35 (m, 1H of cyclopropane), 7.9-8.1 (s, NH of amide), 7.43 (m, 5H, phenylic H), EIMS: $\mathrm{m} / z$ (rel. abundance \%) $406.18(77) \mathrm{M}^{+}$.

1-Cyclopropyl- $\mathrm{N}$-p-tolyl-6-fluoro-4-oxo-7-(piperazinyl)1,4-dihydro-3-quinoline Carboxamide (3b): $\left(\mathrm{C}_{24} \mathrm{H}_{25} \mathrm{FN}_{4} \mathrm{O}_{2}\right)$ yield; $56 \%$, mp $279^{\circ} \mathrm{C}$, IR $(\mathrm{KBr}) v_{\max } ; 1656,1623(\mathrm{C}=\mathrm{O})$ and $3367(\mathrm{~N}-\mathrm{H}) \mathrm{cm}^{-1},{ }^{1} \mathrm{H}-\mathrm{NMR}\left(300 \mathrm{MHz}-\mathrm{CDCl}_{3}\right) \delta 8.09(\mathrm{~s}, 1 \mathrm{H}$, 2'aryl H), 7.19 (d, 1H, 5'aryl H, $J=13.5), 5.93$ (s, 1H, 8'aryl $\mathrm{H}), 2.35$ (m, 3H, methyl $\mathrm{H}), 3.47 ; 2.78(\mathrm{~m}, 8 \mathrm{H}$, piperznyl $\mathrm{H})$, $0.54 ; 028$ ( $\mathrm{m}, 4 \mathrm{H}$, cyclopropane), 1.35 ( $\mathrm{m}, 1 \mathrm{H}$ of cyclopropane), 7.9-8.1 (s, NH of amide) 7.39 (m, 4H, phenylic H), EIMS: $m / z$ (rel. abundance \%) $420.20(37) \mathrm{M}^{+}$.

1-Cyclopropyl- $\mathrm{N}$-(2-hydroxyphenyl)-6-fluoro-4-oxo-7(piperazinyl)-1,4-dihydro-3-quinoline Carboxamide (3c): $\left(\mathrm{C}_{23} \mathrm{H}_{23} \mathrm{FN}_{4} \mathrm{O}_{3}\right)$ yield; 72\%, mp $275{ }^{\circ} \mathrm{C}$, IR (KBr) $v_{\max } ; 1643$, $1625(\mathrm{C}=\mathrm{O})$ and $3176(\mathrm{~N}-\mathrm{H}) \mathrm{cm}^{-1},{ }^{1} \mathrm{H}-\mathrm{NMR}\left(300 \mathrm{MHz}-\mathrm{CDCl}_{3}\right)$ $\delta 8.11$ (s, 1H, 2'aryl H), 7.21 (d, 1H, 5' aryl H, $J=13.1), 5.93$ (s, 1H, 8'arylH), 3.47;2.78 (m, 8H, piperznyl H), 0.53;029 (m, 4H, cyclopropane), 1.35 (m, 1H of cyclopropane), 7.9-8.1 (s, NH of amide), $7.40(\mathrm{~m}, 4 \mathrm{H}$, phenylic H), EIMS: $m / z$ (rel. abundance \%) $422.18(40) \mathrm{M}^{+}$.

1-Cyclopropyl- $\mathrm{N}$-(3-hydroxyphenyl)-6-fluoro-4-oxo7-(piperazinyl)-1,4-dihydro-3-quinoline Carboxamide (3d): $\left(\mathrm{C}_{23} \mathrm{H}_{23} \mathrm{FN}_{4} \mathrm{O}_{3}\right)$ yield; $72 \%$, mp $276{ }^{\circ} \mathrm{C}$, IR $(\mathrm{KBr}) v_{\max } ; 1655$, $1625(\mathrm{C}=\mathrm{O})$ and $3300(\mathrm{~N}-\mathrm{H}) \mathrm{cm}^{-1},{ }^{1} \mathrm{H}-\mathrm{NMR}\left(300 \mathrm{MHz}-\mathrm{CDCl}_{3}\right)$ $\delta 8.09$ (s, 1H, 2'aryl H), 7.20 (d, 1H, 5' aryl H, $J=13.4) 3.47 ; 2.78$ $(\mathrm{m}, 8 \mathrm{H}$, piperznyl $\mathrm{H}), 5.93(\mathrm{~s}, 1 \mathrm{H}, 8$ ' aryl $\mathrm{H}), 0.53 ; 028(\mathrm{~m}, 4 \mathrm{H}$, cyclopropane), 1.35 (m, 1H of cyclopropane), 7.9-8.1 (s, NH of amide), $7.36(\mathrm{~m}, 45 \mathrm{H}$, phenylic H), EIMS: $m / z$ (rel. abundance \%) $422.18(62) \mathrm{M}^{+}$.

1-Cyclopropyl- $N$-(3-aminophenyl)-6-fluoro-4-oxo-7(piperazinyl)-1,4-dihydro-3-quinoline Carboxamide (3e): $\left(\mathrm{C}_{23} \mathrm{H}_{24} \mathrm{FN}_{5} \mathrm{O}_{2}\right)$ yield; $62 \%$, mp $285^{\circ} \mathrm{C}$, IR (KBr) $v_{\max } ; 1653$, $1624(\mathrm{C}=\mathrm{O})$ and $3263(\mathrm{~N}-\mathrm{H}) \mathrm{cm}^{-1},{ }^{1} \mathrm{H}-\mathrm{NMR}\left(300 \mathrm{MHz}-\mathrm{CDCl}_{3}\right)$ $\delta 8.07$ (s, 1H, 2'aryl H), 7.17 (d, 1H, 5'aryl H, $J=13.9) 3.47 ; 2.78$ (m, 8H, piperznyl H), $5.93(\mathrm{~s}, 1 \mathrm{H}, 8$ 'aryl $\mathrm{H}), 0.53 ; 028(\mathrm{~m}, 4 \mathrm{H}$, cyclopropane), 1.35 (m, 1H of cyclopropane), 7.9-8.1 (s, NH of amide) 7.42 (m, 4H, phenylic H), EIMS: $m / z$ (rel. abundance \%) 421.19 (17) $\mathrm{M}^{+}$.

1-Cyclopropyl- $\mathrm{N}$-(4-methoxyphenyl)-6-fluoro-4-oxo-7(piperazinyl)-1,4-dihydro-3-quinoline Carboxamide (3f): $\left(\mathrm{C}_{24} \mathrm{H}_{25} \mathrm{FN}_{4} \mathrm{O}_{3}\right)$ yield; $44 \%$, mp $279{ }^{\circ} \mathrm{C}$, IR (KBr) $v_{\text {max }} ; 1642$, $1619(\mathrm{C}=\mathrm{O})$ and $3166(\mathrm{~N}-\mathrm{H}) \mathrm{cm}^{-1},{ }^{1} \mathrm{H}-\mathrm{NMR}\left(300 \mathrm{MHz}-\mathrm{CDCl}_{3}\right)$ $\delta 8.06$ (s, 1H, 2'aryl H), $7.22(\mathrm{~d}, 1 \mathrm{H}, 5$ ' aryl H, $J=13.5) 3.47 ; 2.75$ (m, 8H, piperznyl H), $5.93(\mathrm{~s}, 1 \mathrm{H}, 8$ 'aryl $\mathrm{H}), 3.73(\mathrm{~s}, 3 \mathrm{H}$, methoxy H), 0.53;029 ( $\mathrm{m}, 4 \mathrm{H}$, cyclopropane), 1.35 (m, $1 \mathrm{H}$ of cyclopropane), 7.9-8.1 (s, NH of amide) 7.49 (m, 4H, phenylic $\mathrm{H})$, EIMS: $m / z$ (rel. abundance \%) 436.19 (41) $\mathrm{M}^{+}$.

1-Cyclopropyl- $N$-(naphthalen-1-yl)-6-fluoro-4-oxo-7(piperazinyl)-1,4-dihydro-3-quinoline Carboxamide (3g): $\left(\mathrm{C}_{27} \mathrm{H}_{25} \mathrm{FN}_{4} \mathrm{O}_{2}\right)$ yield; $39 \%$, mp $277{ }^{\circ} \mathrm{C}$, IR (KBr) v $v_{\text {max }} ; 1649$, $1625(\mathrm{C}=\mathrm{O})$ and $3276(\mathrm{~N}-\mathrm{H}) \mathrm{cm}^{-1},{ }^{1} \mathrm{H}-\mathrm{NMR}\left(300 \mathrm{MHz}^{\left.-\mathrm{CDCl}_{3}\right)}\right.$ $\delta 8.11$ (s, 1H, 2'aryl H), 7.16 (d, 1H, 5' aryl H, $J=13.6) 3.47 ; 2.78$ $(\mathrm{m}, 8 \mathrm{H}$, piperznyl H), $5.93(\mathrm{~s}, 1 \mathrm{H}, 8$ ' aryl $\mathrm{H}), 0.53 ; 029(\mathrm{~m}, 4 \mathrm{H}$, cyclopropane), 1.35 (m, $1 \mathrm{H}$ of cyclopropane), 7.9-8.1 (s, NH of amide) $7.28(\mathrm{~m}, 7 \mathrm{H}$, phenylic $\mathrm{H})$, EIMS: $m / z$ (rel. abundance \%) $456.20(28) \mathrm{M}^{+}$.

1-Cyclopropyl- $N-N$-phenyl-6-fluoro-4-oxo-7-(piperazinyl)1,4-dihydro-3-quinoline Carboxamide (3h): $\left(\mathrm{C}_{23} \mathrm{H}_{24} \mathrm{FN}_{5} \mathrm{O}_{2}\right)$ yield; $51 \%$, mp $281{ }^{\circ} \mathrm{C}$, IR $(\mathrm{KBr}) v_{\max } ; 1635,1619(\mathrm{C}=\mathrm{O})$ and

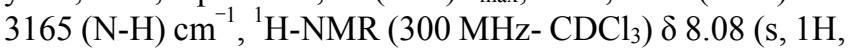
2'aryl H), 7.19 (d, 1H,5' aryl H, $J=12.9) 3.47 ; 2.75(\mathrm{~m}, 8 \mathrm{H}$, piperznyl H), 5.93 (s, 1H, 8'aryl H), 0.53;028 (m, 4H, cyclopropane), 1.35 (m, 1H of cyclopropane), 7.9-8.1 (s, NH of amide) 7.35 (m, 5H, phenylic H), EIMS: $m / z$ (rel. abundance \%) 421.19 (52) $\mathrm{M}^{+}$.

1-Cyclopropyl- $\mathrm{N}$-oxo-phenyl-6-fluoro-4-oxo-7-(piperazinyl)-1,4-dihydro-3-quinoline Carboxamide (3i): $\left(\mathrm{C}_{24} \mathrm{H}_{23} \mathrm{FN}_{4} \mathrm{O}_{3}\right)$ yield; $60 \%$, mp $269^{\circ} \mathrm{C}$, IR $(\mathrm{KBr}) v_{\max } ; 1643,1625(\mathrm{C}=\mathrm{O})$ and $3133(\mathrm{~N}-\mathrm{H}) \mathrm{cm}^{-1},{ }^{1} \mathrm{H}-\mathrm{NMR}\left(300 \mathrm{MHz}-\mathrm{CDCl}_{3}\right) \delta 8.09(\mathrm{~s}, 1 \mathrm{H}$, 2'aryl H), 7.05 (d, 1H, 5' aryl H, $J=13.8) 3.47 ; 2.79(\mathrm{~m}, 8 \mathrm{H}$, piperznyl H), 5.93 (s, 1H, 8'aryl H), 0.53;028 (m, 4H, cyclopropane), 1.36 (m, 1H of cyclopropane), 7.9-8.1 (s, NH of amide) 7.21 (m, 5H, phenylic H), EIMS: $m / z$ (rel. abundance \%) 434.18 (38) $\mathrm{M}^{+}$. 
1-Cyclopropyl- $N$-dioxo-phenyl-6-fluoro-4-oxo-7-(piperazinyl)-1,4-dihydro-3-quinoline Carboxamide (3j): $\left(\mathrm{C}_{25} \mathrm{H}_{22} \mathrm{FN}_{4} \mathrm{O}_{4}\right)$ yield; $69 \%$, mp $287^{\circ} \mathrm{C}$, IR (KBr) $v_{\max } ; 1650,1624(\mathrm{C}=\mathrm{O})$, ${ }^{1} \mathrm{H}-\mathrm{NMR}\left(300 \mathrm{MHz}-\mathrm{CDCl}_{3}\right) \delta 8.11$ (s, 1H, 2'aryl H), 7.22 (d, $1 \mathrm{H}, 5$ 'aryl $\mathrm{H}, J=13.4) 3.47 ; 2.77$ (m, 8H, piperznyl H), 5.93 (s, 1H, 8'aryl H), 0.53;028 (m, 4H, cyclopropane), $1.35(\mathrm{~m}, 1 \mathrm{H}$ of cyclopropane), 7.69;8.13 (m, 4H, phenylic H), EIMS: $m / z$ (rel. abundance \%) $461.16(19) \mathrm{M}^{+}$.

Antimicrobial Assay. The antimicrobial susceptibility of all the derivatives was tested by the disc diffusion technique developed by Bauer et al.. ${ }^{14}$ For this purpose $50 \mu \mathrm{gmL}^{-1}$ stock solution of ciprofloxacin and its derivatives were prepared. The stock solution was diluted to 3 different concentrations i.e. 5, 10 and $20 \mu \mathrm{gmL}^{-1}$. Commercially available filter paper discs were soaked in the prepared drug and derivatives solution, dried and applied on the surface of solid culture media (Nutrient Agar), which had been streaked with standardized bacterial inoculums and incubated at $37^{\circ} \mathrm{C}$ for $24 \mathrm{~h}$. This method is based on the determination of an inhibited zone proportional to the bacterial susceptibility to the antimicrobial present in the disk.

The results were compared with the parent against $11 \mathrm{di}$ fferent strains of Gram positive and Gram negative organism (Staphylococcus aureus, Bacillus subtilis, Streptococcus pneumoniae, Corynebacterium hoffmannii, Klebsiella Pneumoniae, Proteus mirabilis, Shigella flexneri, Escherichia coli, Pseudomonas areuginosa, Citrobacter species, and Salmonella typhi).

Antifungal Assay. For the antifungal assay, $100 \mu \mathrm{gmL}^{-1}$ stock solution of ciprofloxacin and its derivatives were prepared in hot methanol. The stock solutions were diluted to 3 different concentrations i.e. 30,40 and $50 \mu \mathrm{gmL}^{-1}$. Commercially available filter paper discs were impregnated with the prepared solutions of the drugs and its analogues, dried and applied on the surface of the agar plate over which a culture of micro organism was already streaked. After 24 hours of incubation the clear zone of inhibition around the disc was determined, this is proportional to the fungal susceptibility for the antimicrobial agent present in the disk.

Ciprofloxacin and its derivatives were tested for antifungal activity against the fungi; Aspergillus purasiticus, Saccharomyces cervics, Candida albicans and Fusraium solani.

\section{Result and Discussion}

Spectral Analysis. On comparison of the IR spectra of the derivatives with ciprofloxacin revealed that the band at 3520 $\mathrm{cm}^{-1}$ in the ciprofloxacin spectrum, ascribed to the absorption of the carboxylic $\mathrm{OH}$ group was not detected in the spectrum of derivatives, indicating the consumption of carboxylic group in amide formation. However, the IR spectra of all the derivatives exhibit a new band in the region $3100-3350 \mathrm{~cm}^{-1}$ which was allocated to the $\mathrm{NH}$ vibration of amide group. The carboxylic $\mathrm{C}=\mathrm{O}$ absorption was shifted to the right at $1661-1635$ upon amide formation. While absorption of the ring $\mathrm{C}=\mathrm{O}$ at 1625 $\mathrm{cm}^{-1}$ in the spectrum of ciprofloxacin was more or less same in the spectra of the derivatives.

The ${ }^{1} \mathrm{H}$ NMR spectra of derivatives were similar to the ciprofloxacin spectrum except the resonance of acidic proton at 11.02 ppm which was absent in all derivatives spectra, showing the utilization of this moiety in amide formation. Along with the disappearance of carboxylic proton, all derivatives also showed a singlet in the region $7.9-8.1 \mathrm{ppm}$ which corresponds to the absorption of sec-amide. Reaction at carboxylic site of the ciprofloxacin showed a significant difference of the chemical shifts up to 0.5 - $1 \mathrm{ppm}$ of aryl protons in the spectra of all the compounds. The signals for the aliphatic and piperazinyl protons practically remained same as they were distant from the group modification site of the drug. Further signals corresponding to their respective chemical structure are mentioned in the spectral data.

The electron impact mass spectra (EIMS) of ciprofloxacin showed $\mathrm{M}^{+}$peak at $\mathrm{m} / \mathrm{z} 331.54$ which is also the base peak. However all the compounds showed a very low percentage of $\mathrm{M}^{+}$peaks owing to their unstable nature.

Antibacterial Activity. The in vitro antibacterial activity of 3-substituted carboxylic acids against drug-sensitive bacteria Gram positive (Staphylococcus aureus, Bacillus substilis, Streptococcus pneumoniae, Corynebacterium hoffmannii) and Gram negative organisms (Klebsiella Pneumoniae, Proteus mirabilis, Shigella flexneri, Escherichia coli, Pseudomonas areuginosa, Citrobacter species, and Salmonella typhi are summarized in Tables ( $1 \& 2$ ) along with patent drug.

All analogues, we aimed to synthesize showed comparable activity towards ciprofloxacin against all the tested strains. Results indicate that compound 3a was active against Bacillus subtilus and Shigella flexneri while the presence of electron donating group in the phenyl ring $\mathbf{3 b}$ also showed significant activity against Salmonella typhi, Escherichia coli, and Staphylococcus aureus. Introduction of $\mathrm{OH}$ group to aryl amine $\mathbf{3 c}$ showed respectable activity against Bacillus subtilus and Shigella flexneri. Compound 3e, bearing amino group on the phenyl substituent exhibited better activity against Corynebacterium hoffmannii, Pseudomonas areuginosa and Streptococcus pneumoniae. However, methoxy group modification to this primary amine $3 \mathbf{f}$ was of assistance to their antibacterial activities. Compound $\mathbf{3 g}$ have shown significant enhancements of potency against Corynebacterium hoffmannii and Streptococcus pneumonia. It is also meaningful to point out that formation of hydrazide at 3 postion $\mathbf{3 h}$ exhibited the highest activity against most of the Gram-positive strains tested, more potent than reference agent. Compound $\mathbf{3} \mathbf{i}$ and $\mathbf{3} \mathbf{j}$ showed drastically decrease in their activity against all the bacterial tested.

In the terms of structure-activity relationship, results suggest that the antibacterial activity profile against all bacterium was altered by addition of amino group in ciprofloxacin molecule. However, the alteration of substitution in amino ring also made marked differences in activity. It seems that expansion of activity is due to better interaction of molecule with target enzymes or for penetration into these bacteria.

Antifungal Activity. Ciprofloxacin is antimicrobial drug and inactive against fungi, only moxifloxacin and gatifloxacin showed activity against Candida specices ${ }^{15}$ but in order to evaluate the result of addition of different functional groups to its basic structure, the antifungal activity of its derivatives was carried out against various fungi; Aspergillus purasiticus, Saccharomyces cervics, Candida albicans and Fusraium solani. It was found from the result that compounds $\mathbf{3 c}, \mathbf{3 g}$ and $\mathbf{3 h}$ has got 
Table 1. Zone of inhibition ( $\mathrm{mm}$ ) of ciprofloxacin and their derivatives against various microorganisms

\begin{tabular}{|c|c|c|c|c|c|c|c|c|c|c|c|c|c|c|c|c|c|c|}
\hline \multirow{2}{*}{$\frac{\downarrow \text { Organisms }}{\left(\mu \mathrm{gmL}^{-1}\right) \rightarrow}$} & \multicolumn{3}{|c|}{ Ciprofloxacin } & \multicolumn{3}{|c|}{$3 \mathbf{a}$} & \multicolumn{3}{|c|}{$3 \mathbf{b}$} & \multicolumn{3}{|c|}{$3 c$} & \multicolumn{3}{|c|}{ 3d } & \multicolumn{3}{|c|}{$3 \mathbf{e}$} \\
\hline & 5 & 10 & 20 & 5 & 10 & 20 & 5 & 10 & 20 & 5 & 10 & 20 & 5 & 10 & 20 & 5 & 10 & 20 \\
\hline S. aureus & 11 & 14 & 18 & 8 & 13 & 16 & 12 & 19 & 29 & 10 & 14 & 17 & 10 & 14 & 18 & 8 & 12 & 17 \\
\hline Citrobacter & 13 & 19 & 21 & 14 & 17 & 18 & 15 & 19 & 20 & 15 & 17 & 19 & 16 & 16 & 21 & 12 & 19 & 21 \\
\hline S. pneumoniae & 13 & 16 & 21 & 11 & 12 & 14 & 14 & 17 & 21 & 11 & 15 & 18 & 14 & 17 & 20 & 14 & 25 & 28 \\
\hline S. flexneri & 9 & 12 & 17 & 14 & 21 & 25 & 11 & 13 & 16 & 13 & 17 & 29 & 12 & 13 & 16 & 11 & 15 & 16 \\
\hline E. coli & 13 & 16 & 22 & 15 & 16 & 17 & 15 & 20 & 27 & 14 & 16 & 20 & 11 & 16 & 22 & 12 & 15 & 19 \\
\hline S. typhi & 13 & 15 & 20 & 12 & 14 & 16 & 14 & 24 & 30 & 9 & 13 & 18 & 14 & 16 & 19 & 12 & 14 & 16 \\
\hline P. aeruginosa & 13 & 14 & 17 & 11 & 12 & 12 & 11 & 12 & 12 & 12 & 15 & 18 & 12 & 15 & 16 & 10 & 14 & 15 \\
\hline B. substilis & 10 & 12 & 14 & 16 & 22 & 28 & 10 & 11 & 14 & 14 & 25 & 32 & 11 & 13 & 14 & 16 & 20 & 29 \\
\hline K. pneumoniae & 12 & 16 & 24 & 12 & 15 & 18 & 10 & 14 & 18 & 11 & 14 & 18 & 13 & 16 & 22 & 11 & 16 & 22 \\
\hline P. mirabilis & 11 & 14 & 21 & 16 & 19 & 25 & 10 & 11 & 15 & 12 & 13 & 15 & 12 & 13 & 22 & 11 & 13 & 14 \\
\hline C. hofmanii & 10 & 11 & 12 & 8 & 10 & 12 & 10 & 11 & 13 & 10 & 11 & 13 & 9 & 9 & 12 & 14 & 18 & 22 \\
\hline
\end{tabular}

Table 2. Zone of inhibition ( $\mathrm{mm}$ ) of ciprofloxacin and their derivatives against various microorganisms

\begin{tabular}{|c|c|c|c|c|c|c|c|c|c|c|c|c|c|c|c|c|c|c|}
\hline \multirow{2}{*}{$\frac{\downarrow \text { Organisms }}{\left(\mu \mathrm{gmL}^{-1}\right) \rightarrow}$} & \multicolumn{3}{|c|}{ Ciprofloxacin } & \multicolumn{3}{|c|}{$3 f$} & \multicolumn{3}{|c|}{$3 g$} & \multicolumn{3}{|c|}{$3 h$} & \multicolumn{3}{|c|}{$3 \mathbf{i}$} & \multicolumn{3}{|c|}{$3 \mathbf{j}$} \\
\hline & 5 & 10 & 20 & 5 & 10 & 20 & 5 & 10 & 20 & 5 & 10 & 20 & 5 & 10 & 20 & 5 & 10 & 20 \\
\hline S. aureus & 11 & 14 & 18 & 9 & 13 & 15 & 10 & 11 & 18 & 10 & 15 & 17 & 10 & 14 & 15 & 13 & 13 & 17 \\
\hline Citrobacter & 13 & 19 & 21 & 14 & 17 & 19 & 15 & 16 & 20 & 15 & 18 & 20 & 12 & 13 & 17 & 14 & 19 & 20 \\
\hline S. pneumoniae & 13 & 16 & 21 & 11 & 15 & 17 & 16 & 18 & 29 & 14 & 18 & 28 & 14 & 17 & 18 & 12 & 15 & 20 \\
\hline S. flexneri & 9 & 12 & 17 & 18 & 21 & 30 & 11 & 13 & 16 & 9 & 11 & 17 & 11 & 15 & 16 & 10 & 12 & 14 \\
\hline E. coli & 13 & 16 & 22 & 15 & 18 & 21 & 10 & 13 & 20 & 14 & 16 & 20 & 13 & 16 & 21 & 13 & 15 & 19 \\
\hline S. typhi & 13 & 15 & 20 & 12 & 15 & 16 & 14 & 17 & 18 & 12 & 13 & 17 & 10 & 13 & 15 & 12 & 14 & 16 \\
\hline P. aeruginosa & 13 & 14 & 17 & 11 & 15 & 16 & 15 & 19 & 26 & 14 & 19 & 29 & 11 & 13 & 14 & 11 & 14 & 15 \\
\hline B. substilis & 10 & 12 & 14 & 13 & 17 & 27 & 11 & 13 & 14 & 11 & 13 & 16 & 11 & 10 & 12 & 10 & 14 & 15 \\
\hline K. pneumoniae & 12 & 16 & 24 & 12 & 17 & 18 & 12 & 17 & 22 & 11 & 17 & 18 & 9 & 12 & 12 & 11 & 17 & 19 \\
\hline P. mirabilis & 11 & 14 & 21 & 12 & 14 & 20 & 13 & 15 & 20 & 12 & 12 & 15 & 11 & 13 & 14 & 12 & 13 & 14 \\
\hline C. hofmanii & 10 & 11 & 12 & 8 & 10 & 12 & 13 & 16 & 27 & 16 & 19 & 32 & 9 & 9 & 11 & 10 & 10 & 12 \\
\hline
\end{tabular}

Table 3. Zone of inhibition $(\mathrm{mm})$ of ciprofloxacin and compounds against fungi

\begin{tabular}{cccccccc}
\hline & \multicolumn{3}{c}{ Candida albicans } & & \multicolumn{3}{c}{ Fusraium solani } \\
\cline { 2 - 3 } \cline { 6 - 7 } Compounds & $\begin{array}{c}30 \\
\mu \mathrm{gmL}^{-1}\end{array}$ & $\begin{array}{c}40 \\
\mu \mathrm{gmL}^{-1}\end{array}$ & $\begin{array}{c}50 \\
\mu \mathrm{gmL}^{-1}\end{array}$ & $\begin{array}{c}30 \\
\mu \mathrm{gmL}^{-1}\end{array}$ & $\begin{array}{c}40 \\
\mu \mathrm{gmL}^{-1}\end{array}$ & $\begin{array}{c}50 \\
\mu \mathrm{gmL}^{-1}\end{array}$ \\
\hline Ciprofloxacin & - & - & - & - & - & - \\
3a & 9 & 12 & 14 & - & - & - \\
$\mathbf{3 c}$ & 14 & 15 & 15 & & 12 & 14 & 15 \\
3g & 15 & 16 & 17 & & 10 & 12 & 12 \\
3h & 12 & 14 & 15 & 12 & 12 & 14 \\
\hline
\end{tabular}

enhanced activity against Candida albicans and Fusraium solani. The compound 3a also showed moderate activity against Candida albicans. These consequences suggest that antifungal activity of analogues is probably governed by the functional group variation. It is evident that the phenyl attachment via amide linkage of ciprofloxacin has incorporated antifungal property in the drug.

\section{Conclusion}

Conclusively, we have described a convenient synthesis of some derivatives of ciprofloxacin through ester aminolysis. Development of bacterial resistance has led to the synthesis of newer and more potent quinolones. As detailed above, ten carboxamide analogues have been synthesized, characterized and evaluated for their biological activities in vitro in order to discover potent agents against Gram-positive bacteria and Gram negative bacteria.

It was observed that when an aromatic amino group was introduced to carboxylic side, significant enhancements of potency against organisms were achieved from the ciprofloxacin nucleus. Moreover some of the derivatives were also found to be antifungal which is unlike to parent drug.

Acknowledgments. The authors acknowledge Higher Education Commission of Pakistan for providing financial support to Ms. Bushra Rizvi under Indigenous Ph.D. 5000 Scholarship Program Batch III.

\section{References}

1. Hooper, D. C. Biochim. Biophys. Acta 1998, 1400, 45-61.

2. Mascellino, M. T.; Farinelli, S.; Iegri, F.; Iona, E.; De Simone, C. Drugs Expert. Clin. Res. 1998, 24, 139-151.

3. Kampranis, S. C.; Maxwell, A. J. Biol. Chem. 1998, 273(35), 22615-22626.

4. Hooper, D. C. Drug Resist Updates 1999, 2, 38-55.

5. Drlica, K.; Zhao X. Microbiol Mol. Biol. Rev. 1997, 61, 377-392.

6. Jazayeri, S.; Moshafi, M. H.; Firoozpour, L.; Emami, S.; Rajabalian, S.; Haddad, M.; Pahlavanzadeh, F.; Esnaashari, M.; Shafiee, 
A.; Foroumadi, A. European Journal of Medicinal Chemistry 2009, 44, 1205-1209.

7. Foroumadi, A.; Emami, S.; Mehni, M.; Moshafi, M. H.; Shafiee, A. Bioorganic \& Medicinal Chemistry Letters 2005, 15, 4536-4539.

8. Chen, Y. L.; Fang, K. C.; Sheu, J. Y.; Hsu, S. L.; Tzeng, C. C. J. Med. Chem. 2001, 44, 2374-2377.

9. Fang, K. C.; Chen, Y. L.; Sheu, J. Y.; Wang, T. C.; Tzeng, C. C. J. Med. Chem. 2000, 43, 3809-3812.

10. Foroumadi, A.; Mansouri, S.; Kiani, Z.; Rahmani, A. Eur. J. Med. Chem. 2003, 38, 851-854.
11. Ma, X.; Zhou, W.; Brun, R. Bioorganic \& Medicinal Chemistry Letters 2009, 19(3), 986-989.

12. Sultana, N.; Arayne, M. S.; Rizvi, S. B. S.; Mesaik, M. A. Bull. Korean Chem. Soc. 2009, 30(10), 2294-2298.

13. Arayne, M. S.; Sultana, N.; Haroon, U.; Mesaik, M. A.; Asif, M. Arch. Pharm. Res. 2009, 32(7), 967-974.

14. Bauer, A. W.; Kirby, W. M. M.; Sherris, J. C.; Turck, M. Am. J. Clin. Pathol. 1966, 45, 493-496.

15. Ozdek, S. C.; Miller, D.; Flynn, P. M.; Flynn, H. W., Jr. Ocular Infections 2006, 14(6), 347-351. 